\title{
Bioactive compounds content and antimicrobial activities of wild edible Asteraceae species of the Mediterranean flora under commercial cultivation conditions
}

\author{
Spyridon A. Petropoulos ${ }^{\mathrm{a}, *}$, Ângela Fernandes ${ }^{\mathrm{b}}$, Nikolaos Tzortzakis ${ }^{\mathrm{c}}$, Marina Sokovic ${ }^{\mathrm{d}}$, \\ Ana Ciric ${ }^{\mathrm{d}}$, Lillian Barros ${ }^{\mathrm{b}}$, Isabel C.F.R. Ferreira ${ }^{\mathrm{b}, * * *}$

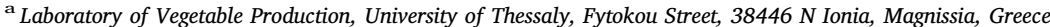 \\ b Centro de Investigação de Montanha (CIMO), Instituto Politécnico de Bragança, Campus de Santa Apolónia, 5300-253 Bragança, Portugal \\ ${ }^{\mathrm{c}}$ Cyprus University of Technology, Department of Agricultural Sciences, Biotechnology and Food Science, 3036 Lemesos, Cyprus \\ ' University of Belgrade, Department of Plant Physiology, Institute for Biological Research "Siniša Stanković", Bulevar Despota Stefana 142, 11000 Belgrade, Serbia
}

\section{A R T I C L E I N F O}

\section{Keywords:}

Wild edible greens

Native species

Antibacterial activities

Antifungal activities

Bioactive compounds

Organic acids

Phenolic compounds

Tocopherols

\begin{abstract}
A B S T R A C T
Nine wild edible species belonging to Astreaceae family, native to the Mediterranean basin were tested for their chemical composition (phenolic compounds, tocopherols, and organic acids) and antimicrobial activities over two growing periods, apart from Scolymus hispanicus and Hedypnois cretica which were tested for only one growing period. Flavonoids were the most abundant phenolic compounds in all the species, except for the case of Taraxacum species where significant amounts of chicoric acid were detected, while phenolic compounds content increased in the 2 nd growing period by $4.6-397.4 \%$ for the tested species. $\alpha$ - and $\beta$-tocopherols were the main tocopherols, apart from Taraxacum sp. where significant amounts of $\gamma$-and $\delta$-tocopherols $(18.32 \mathrm{and} 16.31 \mu \mathrm{g} /$ $100 \mathrm{~g}$ fresh weight) were detected, while total tocopherols content either increased (Reicardia picroides, Picris echioides, Urospermum picroides, and Taraxacum officinale) or decreased (Hymenonema graecum, Sonchus oleraceus, Taraxacum sp.) in the 2nd growing period. Oxalic acid was the most abundant organic acid, with the highest content (972 mg/100 g fresh weight) being observed in H. graecum (L.) DC. in the 1st growing period. Moreover, with the exception of $H$. graecum and $S$. olearaceus, total organic acids content increased in the 2nd growing period. Significant antimicrobial activities were observed against Bacillus cereus, Salmonella typhimurium and Penicillium ochrochloron for all the studied species. In conclusion, the studied species showed great potential for commercial cultivation, while plant extracts could find use in the food industry as alternative food preservatives.
\end{abstract}

\section{Introduction}

Mediterranean basin is abundant with native species which have been traditionally used by the locals for medicinal and therapeutic purposes throughout centuries, while Greece in particular is thriving with numerous ecotypes of such species due to terrain morphology (Psaroudaki, Nikoloudakis, Skaracis, \& Katsiotis, 2015; Vardavas, Majchrzak, Wagner, Elmadfa, \& Kafatos, 2006). Several studies report the significance of these species in human diet, since they have been considered as famine food during harsh time periods of history (Leonti, Nebel, Rivera, \& Heinrich, 2006; Łuczaj \& Dolina, 2015; Pieroni \& Quave, 2014). Consumption of native species is integral part of the socalled Mediterranean diet and has been associated with several beneficial health effects against the maladies that afflict the modern world (Fragopoulou et al., 2012; Guarrera \& Savo, 2013; Pinela, Carvalho, \& Ferreira, 2017; Trichopoulou et al., 2000). Apart from essential nutrients and microelements that enrich and diversify human diet, native species contain high amounts of bioactive compounds that contribute to

\footnotetext{
Abbreviations: DMSO, dimethyl sulfoxide; fw, fresh weight; HPLC, High performance liquid chromatography; LC-DAD-ESI/MSn, liquid chromatography coupled

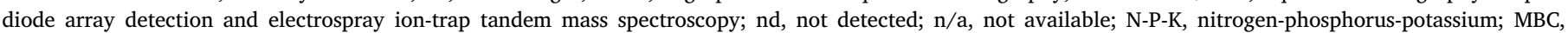

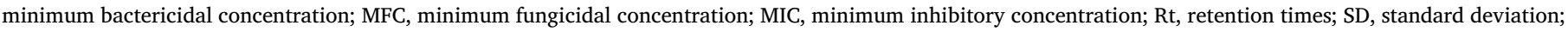
TE, trace elements; UHPLC, Ultra high performance liquid chromatography; UFLC, Ultra fast liquid chromatography; UV, ultraviolet

* Correspondence to: S.A. Petropoulos, University of Thessaly, School of Agricultural Sciences, Fytokou Street, 38446 N Ionia, Magnissia, Greece.

** Correspondence to: I.C.F.R. Ferreira, Centro de Investigação de Montanha (CIMO), Instituto Politécnico de Bragança, Campus de Santa Apolónia, 5300-253 Bragança, Portugal.

E-mail addresses: spetropoulos@uth.gr (S.A. Petropoulos), iferreira@ipb.pt (I.C.F.R. Ferreira).
} 
healthy diets and to maintain or improve physical condition (SánchezMata et al., 2012).

Asteraceae family includes numerous wild edible species that are native in the Mediterranean basin, most of which are consumed for their fresh and tender leaves as salad vegetables (Petropoulos, Ntatsi, Levizou, Barros, \& Ferreira, 2016) or as vegetable mixtures (Guarrera \& Savo, 2016). Chemical composition of native species has gained great research interest during the last decades, due to increased demands from the food industry and consumers for healthy and functional foods, rich in bioactive compounds (Albuquerque et al., 2018; Backes et al., 2018; Giacometti et al., 2018). Many of the reported studies refer to polyphenols, sesquiterpenes, and organic and fatty acids composition which have been associated with positive effects against cardiovascular diseases, cancer, oxidative stress and other diseases (Morales et al., 2012, 2014; Simopoulos, 2004). According to Antonia et al. (2011) and Schütz, Kammerer, Carle, and Schieber (2005), the main phenolic compounds detected in wild Sonchus oleraceus, S. asper and Taraxacum officinale were mainly cichoric acid and cichoric acid derivatives, while verbascoside and isoverbascoside glucosides and chlorogenic acid derivatives were detected in lower amounts. Moreover, Huo and Qin (2008) reported luteolin, apigenin and quercetin as the main flavonoids detected in S. oleraceus, while Dias et al. (2014) identified $\alpha$-tocopherol as the main vitamer of vitamin $\mathrm{E}$ in the vegetative parts of Taraxacum species (Taraxacum sect. Ruderalia). Organic acids are also essential bioactive molecules in native species since they are involved in many biosynthetic pathways, while its composition is also important, especially oxalic acid content which has been associated with antinutritional properties (Guil, Rodríguez-García, \& Torija, 1997).

Although most of these species are traditionally hand-picked in the wild by the locals, the increasing demand for such food products has created a market niche for commercial exploitation of native species in order to fulfill consumer demands for product availability throughout the year, as well as to lessen the risk for genetic erosion due to irrational gathering (Petropoulos et al., 2018). Therefore, recently there are reports for cultivation practices of native species and how these practices may affect its chemical composition and bioactive compounds content (Chatzigianni et al., 2017; Petropoulos et al., 2017; Petropoulos, Karkanis, Martins, \& Ferreira, 2018), as well as reports for potential commercial cultivation of such species (Martinez et al., 2015).

Moreover, apart from raw food consumption the use of wild and under-utilized native species extends to other purposes, including uses in traditional and folk medicine due to their bioactive compounds content and antioxidant potential (Leonti et al., 2006; Sánchez-Mata et al., 2012). Many ethnopharmacological studies confirm the therapeutic effects of wild edible herbs extracts against diabetes, as well as its immunomodulatory, anti-inflammatory and antioxidant properties (Guarrera \& Savo, 2013; Li et al., 2017). Antibacterial properties have been also reported for herb extracts from species such as Sonchus sp. (Xia, Yu, Zhu, \& Zou, 2011) and Taraxacum officinale (Ghaima, Hashim, \& Ali, 2013; Kenny et al., 2014), while several herbal extracts have shown important antifungal activities as alternative post-harvest preservatives in the food industry (Antonia et al., 2011; Antonia, Sergio, Ippolito, \& Di, 2016; Domínguez et al., 2018; Mousavi, Hashemi, \& Limbo, 2018; Pateiro et al., 2018).

The studied species were selected since they have been traditionally used for human consumption and there is a customary use in specific regions of the Mediterranean basin. However, irrational gathering has rendered native species vulnerable to genetic erosion, therefore commercial cultivation could be a useful means towards the conservation of valuable genetic material as well as the creation of a market niche for these products. Considering the importance and the benefits of these species on human diet and their beneficial health effects, the aim of the present study was to report the bioactive compounds content of selected native species of the Asteraceae family, as well as to evaluate their antifungal and antibacterial activities which is rarely explored. Although there are available reports in the literature regarding the chemical composition for several non-cultivated native species, the present study refers to bioactive compounds content of such species under commercial cultivation conditions in order to further evaluate the potential of introducing them as alternative crops.

\section{Materials and methods}

\subsection{Plant material and sampling}

Seeds of selected native species of the Asteraceae family were collected in situ from the broader region of western Crete during spring of 2014 in order to obtain genetic material for species propagation. The selected species were the following: Hedypnois cretica (L.) Schmidt, Hymenonema graecum (L.) DC., Picris echioides (L.) Holub, Reichardia picroides, Scolymus hispanicus, Sonchus oleraceus, Urospermum picroides, Taraxacum officinale and Taraxacum sp. Collected seeds were put in plastic seed trays containing peat (Traysubstrat; Klasmann-Deilmann Gmbt) on October 17th, 2015 (1st growing period; all the species except of $S$. hispanicus and $H$. cretica where no adequate number of seedlings was obtained) and January 17th, 2016 (2nd growing period). Young seedlings were transplanted to $2 \mathrm{~L}$ pots containing peat (Base Substrate 1; Klassman-Deilmann KTS2,1.0 L) and perlite (1.0 L) between December 5th and 13th, 2015 (1st growing period) and March 7th, 2016 (2nd growing period) and when they reached the stage of 3-4 true leaves. After transplantation, pots were transferred in the unheated plastic experimental greenhouse of the University of Thessaly, Greece. During cultivation, plants were irrigated at regular intervals with nutrient solution containing $150 \mathrm{mg} \mathrm{L}^{-1}$ of nitrogen, phosphorus and potassium (N-P-K; water soluble fertilizer 20-20-20 + trace elements (TE)). Harvest took place when plants from each species reached the edible stage by cutting the rosette of leaves and cleaning them with distilled water. Then batch samples of leaves from each species were put in air sealed plastic food bags, stored at deep freezing conditions $\left(-80^{\circ} \mathrm{C}\right)$, and lyophilized prior to further analyses.

Seed collections for all the studied species are deposited in the Laboratory of Vegetable Production, University of Thessaly, Greece.

\subsection{Chemical composition analysis}

\subsubsection{Phenolic composition}

To obtain the extracts, a maceration was performed using a $30 \mathrm{~g} / \mathrm{L}$ solid/liquid ration with methanol/water $\left(80: 20 \mathrm{v} / \mathrm{v}\right.$, at $25^{\circ} \mathrm{C}$ at $150 \mathrm{rpm}$ ) during $60 \mathrm{~min}$, and afterwards filtered (Whatman paper No. 4). The residue was re-extracted with the same solid/liquid ratio and at the same temperature $\left(25^{\circ} \mathrm{C}\right)$. The combined extracts were evaporated under reduced pressure at $35^{\circ} \mathrm{C}$ (rotary evaporator Büchi R-210, Flawil, Switzerland) until complete removal of methanol, and afterwards the aqueous phase was frozen and lyophilized $\left(-49^{\circ} \mathrm{C}\right.$ for $48 \mathrm{~h}$, FeeeZone 4.5, Labconco, Kansas City, MO, USA).

The hydromethanolic extracts (the lyophilized aqueous phase obtained from the evaporation of extracts) were re-dissolved in methanol/ water $(80: 20 \mathrm{v} / \mathrm{v})$ to a final concentration of $10 \mathrm{mg} \mathrm{mL}^{-1}$ for phenolic compound identification and quantification, which was performed in a LC-DAD-ESI/MSn analyses (Dionex Ultimate 3000 UHPLC instrument, Thermo Scientific, San Jose, CA, USA) equipped with a diode-array detector and coupled to a mass detector, following a procedure previously reported by Bessada, Barreira, Barros, Ferreira, and Oliveira (2016). The chromatogram was recorded at several wavelengths, characteristic of different classes of polyphenols (280, 330 and $370 \mathrm{~nm}$ ). For quantitative analysis, a calibration curve for each available phenolic standard (5-100 $\mu \mathrm{g} \mathrm{mL}^{-1}$ ) was constructed based on the UV signal, namely chlorogenic acid, caffeic acid, $p$-coumaric acid, luteolin-7-O-glucoside, apigenin-7-O-glucoside, quercetin-3-O-rutinoside, quercetin-3-O-glucoside, and kaempferol-3-O-rutinoside (Extrasynthesis, Genay, France). For the identified phenolic compounds for which a commercial standard was not available, the quantification was 
Table 1

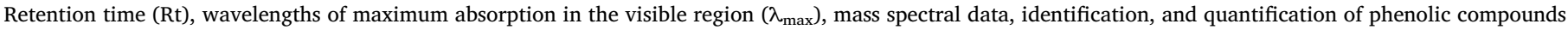
$\left(\mathrm{mg} 100 \mathrm{~g}^{-1} \mathrm{fw}\right)$ in Reichardia picroides and Hymenonema graecum in relation to growing period (1st and $\left.2 \mathrm{nd}\right)$.

\begin{tabular}{|c|c|c|c|c|}
\hline \multirow[t]{2}{*}{ Peaks } & \multirow{2}{*}{$\begin{array}{l}\text { Reichardia picroides } \\
\text { Compounds }\end{array}$} & \multicolumn{2}{|l|}{ Growing period } & \multirow[t]{2}{*}{$t$-Students test $p$-value } \\
\hline & & 1st & 2nd & \\
\hline 2 & trans 5-O-Caffeoylquinic acid & $0.43 \pm 0.03$ & $0.64 \pm 0.04$ & $<0.05$ \\
\hline 7 & Caffeic acid & $\operatorname{tr}$ & $\operatorname{tr}$ & \\
\hline 9 & Kaempferol-O-glucuronyl-O-hexoside & $1.48 \pm 0.01$ & $1.84 \pm 0.02$ & $<0.05$ \\
\hline 20 & Luteolin-7-O-rutinoside & $4.28 \pm 0.01$ & $3.56 \pm 0.09$ & $<0.05$ \\
\hline 24 & Luteolin-7-O-glucoside & $3.5 \pm 0.2$ & $3.98 \pm 0.02$ & $<0.05$ \\
\hline 30 & Apigenin-7-O-rutinoside & $1.44 \pm 0.01$ & $1.89 \pm 0.01$ & $<0.05$ \\
\hline 31 & Apigenin-O-glucuronide & $1.54 \pm 0.05$ & $1.73 \pm 0.03$ & $<0.05$ \\
\hline 33 & Apigenin-7-O-glucoside & $1.43 \pm 0.07$ & $1.99 \pm 0.06$ & $<0.05$ \\
\hline 34 & Luteolin-O-malonylhexoside & $2.3 \pm 0.1$ & $2.28 \pm 0.03$ & 0.49 \\
\hline 35 & Kaempferol-O-glucuronide isomer 2 & $6.26 \pm 0.05$ & $5.5 \pm 0.3$ & $<0.05$ \\
\hline 37 & Kaempferol-glucuronide isomer 3 & $2.01 \pm 0.08$ & $2.2 \pm 0.1$ & 0.06 \\
\hline \multirow[t]{5}{*}{38} & Apigenin- $O$-acetylhexoside & $1.61 \pm 0.05$ & $1.96 \pm 0.06$ & $<0.05$ \\
\hline & Total phenolics acids & $0.43 \pm 0.03$ & $0.64 \pm 0.04$ & $<0.05$ \\
\hline & Total flavonoids & $25.8 \pm 0.6$ & $26.9 \pm 0.2$ & $<0.05$ \\
\hline & Total phenolics compounds & $26.3 \pm 0.6$ & $27.5 \pm 0.2$ & $<0.05$ \\
\hline & Hymenonema graecum & Growing period & & $t$-Students test $p$-value \\
\hline Peaks & Compounds & 1 st & 2nd & \\
\hline 6 & cis 5-p-Coumaroylquinic acid & $0.93 \pm 0.01$ & $0.95 \pm 0.02$ & 0.08 \\
\hline 8 & trans 5 -p-Coumaroylquinic acid & $0.560 \pm 0.002$ & $0.54 \pm 0.02$ & 0.07 \\
\hline 9 & Kaempferol-O-glucuronyl-O-hexoside & $2.28 \pm 0.05$ & $2.29 \pm 0.01$ & $<0.05$ \\
\hline 11 & Luteolin- $O$-glucuronyl- $O$-rutinoside & $6.4 \pm 0.1$ & $7.8 \pm 0.1$ & 0.68 \\
\hline 12 & Luteolin-O-glucuronyl-O-hexoside & $1.50 \pm 0.02$ & $1.64 \pm 0.01$ & $<0.05$ \\
\hline 15 & Luteolin-O-hexoside & $1.60 \pm 0.03$ & $1.80 \pm 0.01$ & $<0.05$ \\
\hline 16 & Apigenin-O-glucuronyl-hexoside & $1.46 \pm 0.03$ & $1.60 \pm 0.01$ & $<0.05$ \\
\hline 20 & Luteolin-7-O-rutinoside & $2.44 \pm 0.03$ & $2.73 \pm 0.08$ & $<0.05$ \\
\hline 21 & Luteolin-O-deoxyhexosyl-O-hexoside & $1.55 \pm 0.03$ & $2.30 \pm 0.08$ & $<0.05$ \\
\hline 24 & Luteolin-7-O-glucoside & $2.1 \pm 0.1$ & $3.1 \pm 0.1$ & $<0.05$ \\
\hline 25 & Luteolin-O-malonylglucuronyl-hexoside & $1.62 \pm 0.05$ & $2.29 \pm 0.07$ & $<0.05$ \\
\hline \multirow[t]{4}{*}{26} & Luteolin-O-malonylhexoside & $1.66 \pm 0.04$ & $1.49 \pm 0.01$ & $<0.05$ \\
\hline & Total phenolics acids & $1.49 \pm 0.01$ & $1.49 \pm 0.01$ & 0.07 \\
\hline & Total flavonoids & $22.7 \pm 0.2$ & $28.2 \pm 0.2$ & $<0.05$ \\
\hline & Total phenolics compounds & $24.2 \pm 0.2$ & $29.7 \pm 0.2$ & $<0.05$ \\
\hline
\end{tabular}

For peak information refer to Table S1.tr - traces (below limit of quantification (LOQ) of the standard compound).

performed through the calibration curve of the most similar available standard. The results were expressed as mg per $100 \mathrm{~g}$ of fresh weight.

\subsubsection{Tocopherols analysis}

Tocopherols were determined following a procedure previously described by Barros et al., 2013; Barros, Pereira, and Ferreira (2013), using the internal standard methodology and using a Knauer Smartline system 1000 (HPLC, Berlin, Germany) coupled to a fluorescence detector (FP-2020; Jasco, Easton, USA). Tocopherols were identified by comparing their retention times with authentic standard compounds and quantification was conducted by comparison with dose-response curves constructed from authentic standards, using the IS (tocol) method. The results were expressed as $\mu \mathrm{g}$ per $100 \mathrm{~g}$ of fresh weight.

\subsubsection{Organic acids analysis}

Organic acids were determined by ultra-fast liquid chromatography (UFLC) (Shimadzu 20A series UFLC, Shimadzu Corporation, Kyoto, Japan) coupled to a diode-array detector (DAD) operating in the conditions described by Barros, Pereira, and Ferreira (2013). The organic acids found were identified and quantified by comparison of the area of their peaks recorded at $215 \mathrm{~nm}$ or $245 \mathrm{~nm}$ (for ascorbic acid) with calibration curves obtained from commercial standards of each compound. The results were expressed as mg per $100 \mathrm{~g}$ of fresh weight.

\subsection{Antimicrobial assays}

The following Gram (+) bacteria: Bacillus cereus (food isolate), Staphylococcus aureus (ATCC 6538) and Listeria monocytogenes (NCTC 7973), Gram (-) bacteria: Escherichia coli (ATCC 35210), Enterobacter cloacae (human isolate), Salmonella typhimurium (ATCC 13311), and fungi: Aspergillus fumigatus (ATCC 1022), Aspergillus ochraceus (ATCC 12066), Aspergillus niger (ATCC 6275), Penicillium ochrochloron (ATCC 9112), Penicillium funiculosum (ATCC 36839) and Penicillium verrucosum var. cyclopium (food isolate) were used in this studied. The antimicrobial assay was carried out by the microdilution method as previously described by Petropoulos, Karkanis, et al. (2018). The concentrations that completely inhibited bacterial growth (minimum inhibitory concentration: MICs) were determined by a colorimetric microbial viability assay, and MBC and MFC (minimum bactericidal concentration and minimum fungicidal concentration, respectively) were also calculated. Streptomycin, aqmpicillin, ketoconazole and bifonazole (Sigma-Aldrich, St. Louis, MO, USA) were used as positive controls and $5 \%$ dimethyl sulfoxide (DMSO) was used as a negative control.

\subsection{Statistical analysis}

For each composition parameter and antimicrobial assays, three samples were analyzed for each treatment, whereas all the assays were carried out in triplicate. The results were expressed as mean values and standard deviations (SD), and analyzed using a Student's $t$-test, with $\alpha=0.05$ (SPSS v. 23.0 program, IBM Corp., Armonk, NY, USA).

\section{Results and discussion}

The phenolic compounds were identified based on their chromatographic, UV-vis and mass spectra characteristics and 38 individual compounds were detected in total: seven phenolic acids and derivatives, 16 flavonol glycoside derivatives and 15 flavone glycoside derivatives (Supplementary Material; Table S1). Compounds 1, 2, and 4-8 
Table 2

Retention time (Rt), wavelengths of maximum absorption in the visible region $\left(\lambda_{\max }\right)$, mass spectral data, identification, and quantification of phenolic compounds (mg $100 \mathrm{~g}^{-1} \mathrm{fw}$ ) in Sonchus oleraceus and Picris echioides in relation to growing period (1st and 2nd).

\begin{tabular}{|c|c|c|c|c|}
\hline \multirow[t]{2}{*}{ Peaks } & \multirow[t]{2}{*}{ Compounds } & \multicolumn{2}{|l|}{ Growing period } & \multirow{2}{*}{$\begin{array}{l}t \text {-Students } \\
\text { test } p \text {-value }\end{array}$} \\
\hline & & $1 \mathrm{st}$ & 2nd & \\
\hline \multicolumn{5}{|c|}{ Sonchus oleraceus } \\
\hline 2 & $\begin{array}{l}\text { trans } 5 \text {-O-caffeoylquinic } \\
\text { acid }\end{array}$ & $2.81 \pm 0.04$ & $1.37 \pm 0.02$ & $<0.05$ \\
\hline 4 & cis Chicoric acid & $2.28 \pm 0.05$ & $2.03 \pm 0.06$ & $<0.05$ \\
\hline 5 & trans Chicoric acid & $1.61 \pm 0.04$ & $1.98 \pm 0.09$ & $<0.05$ \\
\hline 9 & $\begin{array}{l}\text { Kaempferol-O- } \\
\text { glucuronyl-O-hexoside }\end{array}$ & $2.84 \pm 0.03$ & $2.99 \pm 0.05$ & $<0.05$ \\
\hline 13 & Luteolin-O-dihexoside & $2.8 \pm 0.1$ & $3.53 \pm 0.05$ & $<0.05$ \\
\hline 19 & Luteolin-O-glucuronide & $79.9 \pm 0.5$ & $143.8 \pm 0.1$ & $<0.05$ \\
\hline 24 & Luteolin-7-O-glucoside & $12.8 \pm 0.3$ & $23.7 \pm 0.3$ & $<0.05$ \\
\hline 26 & $\begin{array}{l}\text { Quercetin-O- } \\
\text { malonylhexoside }\end{array}$ & $3.50 \pm 0.02$ & $3.42 \pm 0.04$ & $<0.05$ \\
\hline 31 & Apigenin-O-glucoronide & $30.2 \pm 0.6$ & $44 \pm 1$ & $<0.05$ \\
\hline \multirow[t]{4}{*}{34} & $\begin{array}{l}\text { Luteolin- } O \text { - } \\
\text { malonylhexoside }\end{array}$ & $6.32 \pm 0.08$ & $8.29 \pm 0.04$ & $<0.05$ \\
\hline & Total phenolics acids & $6.70 \pm 0.06$ & $5.4 \pm 0.1$ & $<0.05$ \\
\hline & Total flavonoids & $138.2 \pm 0.5$ & $230 \pm 2$ & $<0.05$ \\
\hline & $\begin{array}{l}\text { Total phenolics } \\
\text { compounds }\end{array}$ & $144.9 \pm 0.5$ & $235 \pm 2$ & $<0.05$ \\
\hline \multicolumn{5}{|c|}{ Picris echioides } \\
\hline 2 & $\begin{array}{l}\text { trans } 5 \text {-O-Caffeoylquinic } \\
\text { acid }\end{array}$ & $0.17 \pm 0.01$ & $0.67 \pm 0.01$ & $<0.05$ \\
\hline 3 & $\begin{array}{l}\text { Quercetin- } O \text {-hexosyl- } O \text { - } \\
\text { pentoside isomer } 1\end{array}$ & $1.75 \pm 0.01$ & $4.47 \pm 0.06$ & $<0.05$ \\
\hline 6 & Chicoric acid & $0.42 \pm 0.01$ & $1.61 \pm 0.02$ & $<0.05$ \\
\hline 10 & $\begin{array}{l}\text { Quercetin-O-hexosyl-O- } \\
\text { pentoside isomer } 2\end{array}$ & $2.16 \pm 0.02$ & $3.27 \pm 0.04$ & $<0.05$ \\
\hline 14 & $\begin{array}{l}\text { Kaempferol-O- } \\
\text { dihexoside }\end{array}$ & $1.49 \pm 0.01$ & $1.49 \pm 0.03$ & 0.96 \\
\hline 19 & Luteolin-O-glucuronide & $10.0 \pm 0.1$ & $23.1 \pm 0.2$ & $<0.05$ \\
\hline 24 & Luteolin-7-O-glucoside & $3.65 \pm 0.01$ & $13.4 \pm 0.3$ & $<0.05$ \\
\hline 29 & $\begin{array}{l}\text { Kaempferol- } O \text { - } \\
\text { glucuronide isomer } 1\end{array}$ & $1.39 \pm 0.01$ & $1.64 \pm 0.04$ & $<0.05$ \\
\hline 31 & Apigenin-O-glucuronide & $1.68 \pm 0.02$ & $1.48 \pm 0.05$ & $<0.05$ \\
\hline \multirow[t]{4}{*}{33} & Apigenin-7-O-glucoside & $1.39 \pm 0.06$ & $1.51 \pm 0.07$ & $<0.05$ \\
\hline & Total phenolics acids & $0.586 \pm 0.004$ & $2.28 \pm 0.03$ & $<0.05$ \\
\hline & Total flavonoids & $23.47 \pm 0.03$ & $50.37 \pm 0.6$ & $<0.05$ \\
\hline & $\begin{array}{l}\text { Total phenolics } \\
\text { compounds }\end{array}$ & $24.06 \pm 0.03$ & $52.65 \pm 0.7$ & $<0.05$ \\
\hline
\end{tabular}

For peak information refer to Table S1.

consisted of phenolic acids, more precisely hydroxycinnamic acid derivatives, while compounds 2 (5-O-caffeoylquinic acid) and 7 (caffeic acid) were positively identified according to their retention, mass and UV-vis characteristics by comparison with commercial standards. Compound $1\left([\mathrm{M}-\mathrm{H}]^{-}\right.$at $m / z$ 353) presented the same pseudomolecular ion and fragmentation pattern as compound 2 , being identified as cis 5-O-caffeoylquinic acid. Compounds 6 and $8\left([\mathrm{M}-\mathrm{H}]^{-}\right.$at $\left.\mathrm{m} / \mathrm{z} 353\right)$ presented a base peak at $m / z 191$, accompanied by a weak fragment at $m / z 163$ ([p-coumaric acid- $\mathrm{H}]^{-}$), being identified as cis and trans $5-p$ coumaroylquinic acid. Compounds 4 and $5\left([\mathrm{M}-\mathrm{H}]^{-}\right.$at $\left.m / z 473\right)$ presented a fragmentation pattern that allowed assigning both peaks as cis and trans chicoric acids (dicaffeoyltartaric acid).

The remaining compounds corresponded to flavonoids, namely flavonols (quercetin and kaempferol glycoside derivatives) and flavones (apigenin and luteolin glycoside derivatives). Luteolin glycoside derivatives (compounds 11-13, 15, 19, 20, 21, 24, 25, and 34) were the main detected flavones, while kaempferol glycoside derivatives (compounds $9,14,17,27-29,35,36$, and 37) were the main flavonols. Luteolin ( $\lambda_{\max }$ around $255,265,346 \mathrm{~nm}$, and $\mathrm{MS}^{2}$ fragment at $m / z 285$ ) and kaempferol ( $\lambda_{\max }$ around $270,342 \mathrm{~nm}$, and $\mathrm{MS}^{2}$ fragment at $\mathrm{m} / \mathrm{z}$

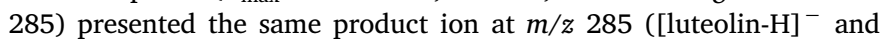
$\left([\mathrm{kaempferol}-\mathrm{H}]^{-}\right)$, being their UV spectra the only method to
Table 3

Retention time (Rt), wavelengths of maximum absorption in the visible region $\left(\lambda_{\max }\right)$, mass spectral data, identification, and and quantification of phenolic compounds (mg $100 \mathrm{~g}^{-1} \mathrm{fw}$ ) in Scolymus hispanicus and Hedypnois cretica in the 2nd growing period.

\begin{tabular}{|c|c|c|}
\hline \multirow[t]{2}{*}{ Peaks } & \multirow[t]{2}{*}{ Compounds } & \multirow{2}{*}{$\begin{array}{l}\text { Growing period } \\
\text { 2nd }\end{array}$} \\
\hline & & \\
\hline \multicolumn{3}{|c|}{ Scolymus hispanicus } \\
\hline 2 & trans 5-O-caffeoylquinic acid & $0.097 \pm 0.003$ \\
\hline 18 & Quercetin-3-O-glucuronide & $1.46 \pm 0.01$ \\
\hline 19 & Luteolin-O-glucuronide & $11.41 \pm 0.24$ \\
\hline 27 & Kaempferol-3-O-rutinoside & $1.35 \pm 0.01$ \\
\hline 29 & Kaempferol-O-glucuronide isomer 1 & $4.67 \pm 0.01$ \\
\hline 31 & Apigenin-O-glucuronide & $3.1 \pm 0.1$ \\
\hline \multirow[t]{4}{*}{32} & Isorhamnetin-O-glucuronide & $1.81 \pm 0.05$ \\
\hline & Total phenolics acids & $0.097 \pm 0.003$ \\
\hline & Total flavonoids & $23.8 \pm 0.1$ \\
\hline & Total phenolics compounds & $23.88 \pm 0.09$ \\
\hline \multicolumn{3}{|c|}{ Hedypnois cretica } \\
\hline 6 & cis 5-p-Coumaroylquinic acid & $0.51 \pm 0.01$ \\
\hline 10 & Quercetin-O-hexosyl-O-pentoside isomer 2 & $1.75 \pm 0.02$ \\
\hline 17 & Kaempferol-O-hexosyl- $O$-pentoside & $1.76 \pm 0.01$ \\
\hline 20 & Luteolin-7-O-rutinoside & $3.07 \pm 0.01$ \\
\hline 24 & Luteolin-7-O-glucoside & $1.90 \pm 0.01$ \\
\hline \multirow[t]{4}{*}{29} & Kaempferol-O-glucuronide isomer 1 & $1.79 \pm 0.01$ \\
\hline & Total phenolics acids & $0.51 \pm 0.01$ \\
\hline & Total flavonoids & $10.27 \pm 0.01$ \\
\hline & Total phenolics compounds & $10.78 \pm 0.01$ \\
\hline
\end{tabular}

For peak information refer to Table S1.

distinguish these two aglycones. Compounds 18 (quercetin-3-O-glucuronide), 20 (luteolin-7-O-rutinoside), 22 (quercetin-3-O-glucoside), 24 (luteolin-7-O-glucoside), 27 (kaempferol-3-O-rutinoside), 28 (kaempferol-3-O-glucoside), 30 (apigenin-7-O-rutinoside), and 33 (apigenin-7-O-glucoside) were positively identified after comparison with commercial standards. Compounds $9\left([\mathrm{M}-\mathrm{H}]^{-}\right.$at $\left.\mathrm{m} / z 623\right), 12$ $\left([\mathrm{M}-\mathrm{H}]^{-}\right.$at $\left.m / z 623\right)$, and $16\left([\mathrm{M}-\mathrm{H}]^{-}\right.$at $\left.m / z 607\right)$ showed a similar fragmentation pattern with the alternative losses of a glucuronyl ( -176 $\mathrm{u}$ ) and hexosyl ( $-162 \mathrm{u}$ ) residues, indicating the location of each residue in different positions of the aglycone; however, no information about the identity of the sugar moieties and the location on the aglycone could be obtained, so the compounds were tentatively identified as kaempferol-O-glucuronyl-O-hexoside, luteolin-O-glucuronyl-O-hexoside, and apigenin-O-glucuronyl-O-hexoside, respectively. Similarly, peak $11\left([\mathrm{M}-\mathrm{H}]^{-}\right.$at $m / z$ 769) presented a $\mathrm{MS}^{2}$ fragmentation with the alternative loss of glucuronyl $(\mathrm{m} / \mathrm{z}$ at $593 ;-176 \mathrm{u})$ and deoxyhexosylhexoside $(\mathrm{m} / \mathrm{z}$ at $285 ;-308 \mathrm{u})$ residues. Nevertheless, the positive identification of different rutinosides, including luteolin-7-O-rutinoside, may suggest the tentative identification of this compound as luteolin- $O$ glucuronyl-O-rutinoside. Compounds 3 and $10\left([\mathrm{M}-\mathrm{H}]^{-}\right.$at $\mathrm{m} / z$ 595), and $17\left([\mathrm{M}-\mathrm{H}]^{-}\right.$at $\left.m / z 579\right)$, revealed the alternative losses of hexosyl $(-162 \mathrm{u})$ and pentosyl $(-132 \mathrm{u})$ moieties; taking into account the above findings, these compounds were identified as quercetin- $O$-hexosyl-O-pentoside isomers 1 and 2, and kaempferol-O-hexosyl-O-pentoside, respectively.

The mass characteristics and UV spectra of compounds 13 and 14 $\left([\mathrm{M}-\mathrm{H}]^{-}\right.$at $\left.m / z 609\right)$ showed that they correspond to luteolin and kaempferol derivatives bearing two hexosyl residues, while the observation of only one $\mathrm{MS}^{2}$ fragment suggested that the two sugars were linked together, thus being tentatively identified as luteolin- $O$-dihexoside and kaempferol-O-dihexoside, respectively. Compounds 15 $\left([\mathrm{M}-\mathrm{H}]^{-}\right.$at $\left.m / z 447\right)$ and $23\left([\mathrm{M}-\mathrm{H}]^{-}\right.$at $\left.m / z 463\right)$ presented the loss of a hexosyl moiety $(-162 \mathrm{u})$, and showed the same pseudomolecular ion as compounds 24 (luteolin-7-O-glucoside) and 22 (quercetin-3-O-glucoside), thus presenting a different retention time in comparison with the commercial standard. Therefore they could be assumed as a luteolin- $O$-hexoside and quercetin- $O$-hexoside, 
Table 4

Retention time (Rt), wavelengths of maximum absorption in the visible region $\left(\lambda_{\max }\right)$, mass spectral data, identification, and quantification of phenolic compounds (mg $100 \mathrm{~g}^{-1} \mathrm{fw}$ ) in Urospermum picroides, Taraxacum sp. and T. officinale in relation to growing period (1st and $2 \mathrm{nd}$ ).

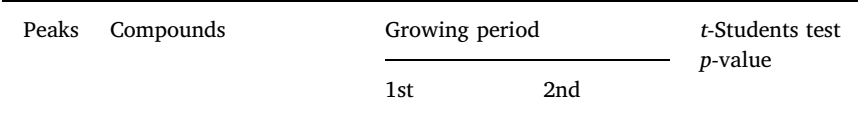

\begin{tabular}{|c|c|c|c|c|}
\hline \multicolumn{5}{|c|}{ Urospermum picroides } \\
\hline 1 & $\begin{array}{l}\text { cis } 5 \text {-O-caffeoylquinic } \\
\text { acid }\end{array}$ & $0.68 \pm 0.02$ & $1.80 \pm 0.02$ & $<0.05$ \\
\hline 2 & $\begin{array}{l}\text { trans } 5 \text {-O-caffeoylquinic } \\
\text { acid }\end{array}$ & $0.53 \pm 0.01$ & $2.06 \pm 0.04$ & $<0.05$ \\
\hline 6 & $\begin{array}{l}\text { cis 5-p-coumaroylquinic } \\
\text { acid }\end{array}$ & $0.50 \pm 0.01$ & $0.57 \pm 0.01$ & $<0.05$ \\
\hline 22 & Quercetin-3-O-glucoside & $2.41 \pm 0.06$ & $3.47 \pm 0.09$ & $<0.05$ \\
\hline 23 & Quercetin-O-hexoside & $1.7 \pm 0.1$ & $2.04 \pm 0.04$ & $<0.01$ \\
\hline 26 & $\begin{array}{l}\text { Quercetin- } O \text { - } \\
\text { malonylhexoside }\end{array}$ & $4.12 \pm 0.01$ & $4.22 \pm 0.03$ & $<0.05$ \\
\hline 28 & $\begin{array}{l}\text { Kaempferol-3-O- } \\
\text { glucoside }\end{array}$ & $1.48 \pm 0.01$ & $1.55 \pm 0.01$ & $<0.05$ \\
\hline \multirow[t]{4}{*}{36} & $\begin{array}{l}\text { Kaempferol-O- } \\
\text { malonylhexoside }\end{array}$ & $1.40 \pm 0.01$ & $1.46 \pm 0.01$ & $<0.05$ \\
\hline & Total phenolics acids & $1.71 \pm 0.03$ & $4.43 \pm 0.08$ & $<0.05$ \\
\hline & Total flavonoids & $11.1 \pm 0.2$ & $12.74 \pm 0.2$ & $<0.05$ \\
\hline & $\begin{array}{l}\text { Total phenolics } \\
\text { compounds }\end{array}$ & $12.8 \pm 0.2$ & $17.18 \pm 0.3$ & $<0.05$ \\
\hline \multicolumn{5}{|c|}{ Taraxacum sp. } \\
\hline 5 & trans Chicoric acid & $0.67 \pm 0.01$ & $14.9 \pm 0.3$ & $<0.05$ \\
\hline \multirow[t]{4}{*}{20} & Luteolin-7-O-rutinoside & $3.25 \pm 0.06$ & $4.51 \pm 0.01$ & $<0.05$ \\
\hline & Total phenolics acids & $0.67 \pm 0.01$ & $14.9 \pm 0.3$ & $<0.05$ \\
\hline & Total flavonoids & $3.25 \pm 0.06$ & $4.51 \pm 0.01$ & $<0.05$ \\
\hline & $\begin{array}{l}\text { Total phenolics } \\
\text { compounds }\end{array}$ & $3.92 \pm 0.07$ & $19.5 \pm 0.4$ & $<0.05$ \\
\hline \multicolumn{5}{|c|}{ Taraxacum officinale } \\
\hline 5 & trans Chicoric acid & $1.65 \pm 0.02$ & $2.79 \pm 0.05$ & $<0.05$ \\
\hline \multirow[t]{4}{*}{20} & Luteolin-7-O-rutinoside & $2.49 \pm 0.1$ & $2.88 \pm 0.04$ & $<0.05$ \\
\hline & Total phenolics acids & $1.65 \pm 0.02$ & $2.79 \pm 0.05$ & $<0.05$ \\
\hline & Total flavonoids & $2.49 \pm 0.01$ & $2.88 \pm 0.04$ & $<0.05$ \\
\hline & $\begin{array}{l}\text { Total phenolics } \\
\text { compounds }\end{array}$ & $4.14 \pm 0.01$ & $5.68 \pm 0.02$ & $<0.05$ \\
\hline
\end{tabular}

For peak information refer to Table S1.

respectively. Similarly, compound $21\left([\mathrm{M}-\mathrm{H}]^{-}\right.$at $\left.m / z 593\right)$ was identified as luteolin-O-deoxyhexosyl-hexoside. Peaks $19\left([\mathrm{M}-\mathrm{H}]^{-}\right.$at $m / z 461), 31\left([\mathrm{M}-\mathrm{H}]^{-}\right.$at $\left.m / z 445\right), 29,35$, and $37\left([\mathrm{M}-\mathrm{H}]^{-}\right.$at $m / z$ $461)$ and $32\left([\mathrm{M}-\mathrm{H}]^{-}\right.$at $m / z$ 491) were identified as glucuronyl derivatives $(-176 \mathrm{u})$ of luteolin, apigenin, kaempferol and isorhamnetin, respectively.

Compounds $25\left([\mathrm{M}-\mathrm{H}]^{-}\right.$at $\left.m / z 709\right), 26\left([\mathrm{M}-\mathrm{H}]^{-}\right.$at $\left.m / z 549\right)$, $34\left([\mathrm{M}-\mathrm{H}]^{-}\right.$at $\left.m / z 533\right)$ and $36\left([\mathrm{M}-\mathrm{H}]^{-}\right.$at $\left.m / z 533\right)$ possessed molecular weights $86 \mathrm{u}$ higher than peaks 12, 22, 24, and 28, indicating the existence of an additional malonyl residue, thus being tentatively identified as luteolin- $O$-malonylglucuronyl-hexoside, quercetin- $O$-malonylhexoside, luteolin-O-malonylhexoside, and kaempferol-O-malonylhexoside. Likewise, peak $38\left([\mathrm{M}-\mathrm{H}]^{-}\right.$at $\mathrm{m} / z$ 473) presented a molecular weight $42 \mathrm{u}$ higher than peak 33, revealing the existence of an acetyl moiety, thus being tentatively identified as apigenin- $O$-acetylhexoside.

The phenolic composition of Reichardia picroides and Hymenonema graecum is presented in Table 1 . For $R$. picroides twelve phenolic compounds were identified with kaempferol-3-O-glucuronide being the most abundant compound, followed by luteolin-7-O-rutinoside and luteolin-7-O-glucoside. Luteolin derivatives in methanolic extracts of $R$. picroides have been previously reported by Recio et al. (1992) who also detected chlorogenic and isochlorogenic acid. In the case of $H$. graecum, twelve individual phenolic compounds were identified with luteolin- $O$ glucuronyl-O-hexoside being the most abundant molecule, followed by other luteolin derivatives which were detected in lower amounts. Moreover, phenolic compounds content was higher in the second growing period for both species due to a slight increase of both phenolic acids and flavonoids.

Table 2 presents the phenolic compounds profile of Sonchus oleraceus and Picris echioides. Ten individual phenolic compounds were detected in $S$. oleraceus aerial parts extracts, with luteolin and apigenin derivatives being the most abundant ones, accounting for $91.1 \%$ and $95.0 \%$ of total phenolic compounds in the 1 st and 2 nd growing period, respectively. Similarly, ten individual phenolic compounds were also identified in $P$. echioides, with luteolin and apigenin derivatives being the most abundant ones, accounting for $91.1 \%$ and $95.0 \%$ of total phenolic compounds in the 1st and 2nd growing period, respectively. However, a difference in the overall composition was observed between these two species. Moreover, a significant increase in phenolic compounds content was observed in the 2 nd growing period for both species. According to Giner et al. (1993), luteolin and apigenin derivatives were also detected in $S$. oleraceus after using a Soxhlet extraction with $\mathrm{CH}_{2} \mathrm{Cl}_{2}$ and $\mathrm{MeOH}$, while the authors reported that luteolin-7-O-glucoside is wide-present among the various Sonchus species. However, a different composition of phenolic compounds was detected in that study which could be due to different extraction method comparing to the method implemented in our study (non-thermal stirring hydromethanolic extraction). Similarly, Kenny et al. (2014) reported that luteolin derivatives were the main flavone glucosides detected in ethanolic extracts of $S$. asper aerial parts, while they also identified chlorogenic acid and quinic acid in significant amounts. In contrast, Morales et al. (2014) have reported that a lower portion of total phenols consists of flavonoids, which could be due to different growing conditions and cultivation practices (wild versus cultivated species), as well as to different geographical origin (Schaffer, Schmitt-Schillig, Müller, \& Eckert, 2005) and extraction method (Dias et al., 2014), comparing to our study.

The phenolic composition of Scolymus hispanicus and Hedypnois cretica is presented in Table 3 . For both species only data from the 2nd growing period are available due to insufficient number of plants in the 1 st growing period. The most abundant compounds were luteolin-Oglucuronide and luteolin-7-O-rutinoside for $S$. hispanicus and $H$. cretica, respectively, while phenolic compounds consisted mostly of flavonoids in both species. Table 4 shows the phenolic compounds profile of $U r$ ospermum picroides, Taraxacum sp., and T. officinale. Quercetin-O-malonylhexoside was the most abundant phenolic compound in the case of $U$. picroides, while for both Taraxacum species the main compounds were luteolin-7-O-rutinoside and chicoric acid, especially in the case of Taraxacum sp. and the 2nd growing period where the highest amount of chicoric acid was observed. The results for Taraxacum species are in agreement with the study of Dias et al. (2014) who also reported chicoric acid as the main phenolic compound in vegetative parts of Taraxacum sect. Ruderalia, as well as with the study of Chen, Inbaraj, and Chen (2012) who evaluated phenolic compounds composition of $T$. formosanum Kitam. The overall phenolic compounds content increased in the 2nd growing period, as it is already reported for the rest of the studied species, however in the case of Taraxacum species this was due to the increase of phenolic acids content instead of an increase in flavonoids content.

Considering that 2nd growing period and harvest of plants took place under higher temperatures and light intensity levels (mid-late spring comparing to winter-early spring for the 2nd and 1st growing period, respectively) it could be assumed that plants were subjected to stress conditions under the 2 nd growing period that could induce the biosynthesis of phenolic compounds (Fallovo, Schreiner, Schwarz, Colla, \& Krumbein, 2011), while Pérez-López, Miranda-Apodaca, Muñoz-Rueda, and Mena-Petite (2015) have also reported that high light intensity may increase total phenols content in lettuce leaves. Similarly, according to Petropoulos, Karkanis, et al. (2018) not only growing season but also harvesting stage has a significant effect on total phenolic content and phenolic compounds composition, while Becker, Klaering, Schreiner, Kroh, and Krumbein (2014) reported that plant age 
Table 5

Composition in tocopherols ( $\mu \mathrm{g} 100 \mathrm{~g}^{-1} \mathrm{fw}$ ) and organic acids (mg $100 \mathrm{~g}^{-1} \mathrm{fw}$ ) of the studied wild species (mean \pm SD).

\begin{tabular}{|c|c|c|c|c|c|c|}
\hline Species & Growing period & $\alpha$-Tocopherol & $\beta$-Tocopherol & $\gamma$-Tocopherol & $\delta$-Tocopherol & Total Tocopherols \\
\hline \multirow[t]{3}{*}{ Reichardia picroides } & 1st & $2.54 \pm 0.08$ & nd & nd & nd & $2.54 \pm 0.08$ \\
\hline & 2nd & $3.51 \pm 0.07$ & $1.4 \pm 0.2$ & nd & nd & $4.9 \pm 0.2$ \\
\hline & $t$-Students test $p$-value & $<0.05$ & $\mathrm{n} / \mathrm{a}$ & $\mathrm{n} / \mathrm{a}$ & $\mathrm{n} / \mathrm{a}$ & \\
\hline \multirow[t]{3}{*}{ Hymenonema graecum } & 1 st & $2.78 \pm 0.08$ & $2.10 \pm 0.08$ & nd & nd & $4.88 \pm 0.01$ \\
\hline & 2nd & $1.05 \pm 0.06$ & $2.14 \pm 0.06$ & nd & nd & $3.2 \pm 0.1$ \\
\hline & $t$-Students test $p$-value & $<0.05$ & 0.39 & $\mathrm{n} / \mathrm{a}$ & $\mathrm{n} / \mathrm{a}$ & $<0.05$ \\
\hline \multirow[t]{3}{*}{ Sonchus oleraceus } & 1st & $2.2 \pm 0.2$ & $1.8 \pm 0.2$ & nd & nd & $3.93 \pm 0.05$ \\
\hline & 2nd & $2.29 \pm 0.05$ & $1.55 \pm 0.01$ & nd & nd & $3.84 \pm 0.05$ \\
\hline & $t$-Students test $p$-value & 0.15 & 0.08 & $\mathrm{n} / \mathrm{a}$ & $\mathrm{n} / \mathrm{a}$ & $<0.05$ \\
\hline Scolymus* hispanicus & 2nd & $0.68 \pm 0.02$ & $0.85 \pm 0.07$ & nd & nd & $1.53 \pm 0.09$ \\
\hline Hedypnois* cretica & 2nd & $2.33 \pm 0.07$ & nd & nd & nd & $2.33 \pm 0.06$ \\
\hline \multirow[t]{3}{*}{ Picris echioides } & 1 st & $1.26 \pm 0.03$ & nd & nd & nd & $1.27 \pm 0.02$ \\
\hline & 2nd & $2.64 \pm 0.06$ & nd & nd & nd & $2.65 \pm 0.06$ \\
\hline & $t$-Students test $p$-value & $<0.05$ & $\mathrm{n} / \mathrm{a}$ & $\mathrm{n} / \mathrm{a}$ & $\mathrm{n} / \mathrm{a}$ & $<0.05$ \\
\hline \multirow[t]{3}{*}{ Urospermum picroides } & $1 \mathrm{st}$ & $1.54 \pm 0.09$ & nd & nd & nd & $1.54 \pm 0.08$ \\
\hline & 2nd & $1.58 \pm 0.08$ & nd & nd & nd & $1.58 \pm 0.08$ \\
\hline & $t$-Students test $p$-value & 0.46 & $\mathrm{n} / \mathrm{a}$ & $\mathrm{n} / \mathrm{a}$ & $\mathrm{n} / \mathrm{a}$ & 0.46 \\
\hline \multirow[t]{3}{*}{ Taraxacum sp. } & 1st & $9.6 \pm 0.6$ & $5.2 \pm 0.3$ & $18.3 \pm 0.2$ & $16.3 \pm 0.6$ & $49.4 \pm 0.5$ \\
\hline & 2nd & $4.02 \pm 0.01$ & $2.9 \pm 0.2$ & nd & nd & $6.9 \pm 0.2$ \\
\hline & $t$-Students test $p$-value & $<0.05$ & $<0.05$ & $\mathrm{n} / \mathrm{a}$ & $\mathrm{n} / \mathrm{a}$ & $<0.05$ \\
\hline \multirow[t]{3}{*}{ Taraxacum officinale } & 1 st & $2.05 \pm 0.08$ & $2.8 \pm 0.1$ & nd & nd & $4.9 \pm 0.2$ \\
\hline & 2nd & $2.13 \pm 0.09$ & $1.57 \pm 0.09$ & nd & nd & $3.7 \pm 0.2$ \\
\hline & $t$-Students test $p$-value & 0.21 & $<0.05$ & $\mathrm{n} / \mathrm{a}$ & $\mathrm{n} / \mathrm{a}$ & $<0.05$ \\
\hline Species & Growing period & Oxalic acid & Malic acid & Shikimic acid & Total organic acids & \\
\hline \multirow[t]{3}{*}{ Reichardia picroides } & 1 st & $625 \pm 6$ & $91.7 \pm 0.8$ & $2.22 \pm 0.02$ & $719 \pm 3$ & \\
\hline & 2nd & $937 \pm 4$ & $73 \pm 2$ & $144.0 \pm 0.2$ & $1154 \pm 2$ & \\
\hline & $t$-Students test $p$-value & $<0.05$ & $<0.05$ & $<0.05$ & $<0.05$ & \\
\hline \multirow[t]{3}{*}{ Hymenonema graecum } & 1 st & $972 \pm 2$ & $110 \pm 4$ & $244 \pm 1$ & $1326 \pm 2$ & \\
\hline & 2nd & $877 \pm 3$ & $61 \pm 3$ & $166 \pm 4$ & $1103 \pm 1$ & \\
\hline & $t$-Students test $p$-value & $<0.05$ & $<0.05$ & $<0.05$ & $<0.05$ & \\
\hline \multirow[t]{3}{*}{ Sonchus oleraceus } & 1 st & $777 \pm 3$ & $415 \pm 2$ & $167 \pm 3$ & $1359.7 \pm 0.4$ & \\
\hline & 2nd & $644 \pm 1$ & $444 \pm 2$ & $146 \pm 6$ & $1233 \pm 2$ & \\
\hline & $t$-Students test $p$-value & $<0.05$ & $<0.05$ & $<0.05$ & $<0.05$ & \\
\hline Scolymus hispanicus* & 2nd & $564 \pm 2$ & $18 \pm 1$ & $34.4 \pm 0.1$ & $617 \pm 1$ & \\
\hline Hedypnois cretica* & 2nd & $631 \pm 5$ & $299 \pm 2$ & $128 \pm 2$ & $1059 \pm 2$ & \\
\hline \multirow[t]{3}{*}{ Picris echioides } & 1 st & $562.7 \pm 0.7$ & $105 \pm 2$ & $87.1 \pm 0.5$ & $755 \pm 1$ & \\
\hline & 2nd & $638 \pm 6$ & $216 \pm 3$ & $149 \pm 2$ & $1003 \pm 3$ & \\
\hline & $t$-Students test $p$-value & $<0.05$ & $<0.05$ & $<0.05$ & $<0.05$ & \\
\hline \multirow[t]{3}{*}{ Urospermum picroides } & 1 st & $574 \pm 1$ & $248 \pm 3$ & $75 \pm 2$ & $897 \pm 1$ & \\
\hline & 2nd & $660 \pm 4$ & $383 \pm 4$ & $89 \pm 3$ & $1132 \pm 1$ & \\
\hline & $t$-Students test $p$-value & $<0.05$ & $<0.05$ & $<0.05$ & $<0.05$ & \\
\hline \multirow[t]{3}{*}{ Taraxacum sp. } & 1 st & $370 \pm 4$ & $133 \pm 1$ & $59 \pm 3$ & $562 \pm 1$ & \\
\hline & 2nd & $541 \pm 2$ & $136.3 \pm 0.1$ & $86 \pm 3$ & $763 \pm 1$ & \\
\hline & $t$-Students test $p$-value & $<0.05$ & $<0.05$ & $<0.05$ & $<0.05$ & \\
\hline \multirow[t]{3}{*}{ Taraxacum officinale } & 1 st & $386.8 \pm 0.3$ & $220 \pm 4.0$ & $53.2 \pm 0.2$ & $660 \pm 2$ & \\
\hline & 2nd & $462 \pm 1$ & $175 \pm 5$ & $72 \pm 2$ & $708 \pm 2$ & \\
\hline & $t$-Students test $p$-value & $<0.05$ & $<0.05$ & $<0.05$ & $<0.05$ & \\
\hline
\end{tabular}

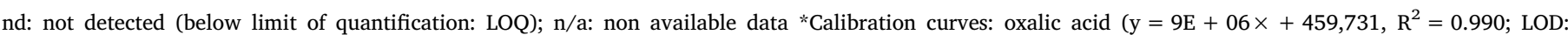

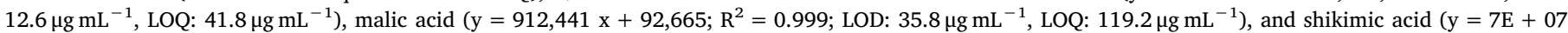
$\mathrm{x}+175,156 ; \mathrm{R}^{2}=0.999$; LOD: $10.2 \mu \mathrm{g} \mathrm{mL}^{-1}$, LOQ: $56.5 \mu \mathrm{g} \mathrm{mL}^{-1}$ ).

and ontogeny are essential for phenolic compounds composition. Therefore, differences in growing conditions between the growing periods of the present study could induce the biosynthetic pathways of phenolic compounds and result in a higher content in the 2nd growing period comparing to the 1 st one.

Phenolic compounds composition showed a great diversity among the studied species with 38 different compounds being detected (Supplementary Material; Table S1). Among these compounds, only 12 were common in two or more species, whereas the rest of the compounds were unique for the studied species (Supplementary Material; Table S2). In addition, S. oleraceus had the highest content in total phenolic compounds among the studied species due to the highest content in flavonoids, and luteolin-O-glucuronide in particular. The abundance of $S$. oleraceus in phenolic compounds has been reported by Xia et al. (2011) who also suggested that the species had the highest content in total flavonoids among six Sonchus species. The prevalent phenolic compounds in the species of our study were mostly flavonoids derivatives (luteolin, apigenin, kaempferol, and quercetin glycoside derivatives), whereas only in the case of $T$. officinale phenolic acids comprised a significant portion of total phenolic compounds, especially in the 2nd growing period where the amount of phenolic acids was equal to that of total flavonoids (Table 4).

Tocopherols content is presented in Table 5. The main tocopherol was $\alpha$-tocopherol which was detected in all the studied species for both growing periods, while $\beta$-tocopherol was detected only in $H$. graecum and $S$. oleraceus in both growing periods and in R. picroides and S. hispanicus in the 2nd growing period. Moreover, Taraxacum sp. was the only species where all tocopherol isoforms were detected in the 1st growing period. Similarly, Morales et al. (2014) reported that $\alpha$-tocopherol was the main tocopherol in $S$. oleraceus, while $\alpha$ - and $\beta$-tocopherols were detected in similar amounts in $S$. hispanicus. However, in contrast with our study they also detected $\gamma$ - and $\delta$-tocopherols in $S$. oleraceus plants, which could be due to different growing conditions comparing to our study. In addition and in contrast with the above mentioned study, Conforti et al. (2011) did not detect tocopherols in leaves samples of $S$. oleraceus collected in Italy, which further highlights 
Table 6

Antimicrobial activity of the studied wild species (MIC and MBC $\mathrm{mg} \mathrm{mL}^{-1}$ ).

\begin{tabular}{|c|c|c|c|c|c|c|c|c|}
\hline \multirow[t]{2}{*}{ Species } & \multirow{2}{*}{$\begin{array}{l}\text { Growing } \\
\text { period }\end{array}$} & \multicolumn{7}{|c|}{ Antibacterial activity } \\
\hline & & & Bacillus cereus & Staphylococcus aureus & $\begin{array}{l}\text { Listeria } \\
\text { monocytogenes }\end{array}$ & Escherichia coli & Enterobacter cloacae & $\begin{array}{l}\text { Salmonella } \\
\text { typhimurium }\end{array}$ \\
\hline \multirow[t]{4}{*}{ Reichardia picroides } & \multirow[t]{2}{*}{1 st } & MIC & 0.15 & 0.30 & 0.30 & 0.15 & 0.30 & 0.30 \\
\hline & & MBC & 0.30 & 0.60 & 0.60 & 0.30 & 0.60 & 0.60 \\
\hline & \multirow[t]{2}{*}{ 2nd } & MIC & 0.15 & 0.30 & 0.30 & 0.30 & 0.30 & 0.60 \\
\hline & & MBC & 0.30 & 0.60 & 0.60 & 0.60 & 0.60 & 0.90 \\
\hline \multirow{4}{*}{$\begin{array}{c}\text { Hymenonema } \\
\text { graecum }\end{array}$} & \multirow[t]{2}{*}{$1 \mathrm{st}$} & MIC & 0.20 & 0.60 & 0.60 & 0.60 & 0.45 & 0.30 \\
\hline & & MBC & 0.30 & 0.90 & 1.20 & 0.90 & 0.90 & 0.60 \\
\hline & \multirow[t]{2}{*}{ 2nd } & MIC & 0.20 & 0.60 & 0.60 & 0.60 & 0.60 & 0.30 \\
\hline & & MBC & 0.30 & 1.20 & 0.90 & 1.20 & 1.20 & 0.60 \\
\hline \multirow[t]{4}{*}{ Sonchus oleraceus } & \multirow[t]{2}{*}{$1 \mathrm{st}$} & MIC & 0.20 & 0.45 & 0.45 & 0.45 & 0.60 & 0.45 \\
\hline & & MBC & 0.30 & 0.60 & 0.60 & 0.60 & 0.90 & 0.90 \\
\hline & 2nd & MIC & 0.15 & 0.30 & 0.60 & 0.30 & 0.30 & 0.30 \\
\hline & & MBC & 0.30 & 0.60 & 0.90 & 0.60 & 0.60 & 0.60 \\
\hline Scolymus hispanicus & 2nd & MIC & 0.10 & 0.30 & 0.20 & 0.10 & 0.15 & 0.15 \\
\hline & & MBC & 0.15 & 0.60 & 0.60 & 0.15 & 0.30 & 0.30 \\
\hline Hedypnois cretica & 2nd & MIC & 0.15 & 0.60 & 0.45 & 0.20 & 0.30 & 0.30 \\
\hline & & MBC & 0.30 & 0.90 & 0.60 & 0.30 & 0.60 & 0.60 \\
\hline Picris echioides & $1 \mathrm{st}$ & MIC & 0.075 & 0.45 & 0.60 & 0.45 & 0.30 & 0.60 \\
\hline & & MBC & 0.15 & 0.60 & 0.90 & 0.60 & 0.60 & 0.90 \\
\hline & 2nd & MIC & 0.15 & 0.30 & 0.30 & 0.15 & 0.20 & 0.20 \\
\hline & & MBC & 0.30 & 0.60 & 0.60 & 0.30 & 0.30 & 0.30 \\
\hline Urospermum picroides & $1 \mathrm{st}$ & MIC & 0.15 & 0.90 & 0.90 & 0.90 & 0.45 & 0.45 \\
\hline & & MBC & 0.30 & 1.20 & 1.20 & 1.20 & 0.90 & 0.90 \\
\hline & 2nd & MIC & 0.15 & 0.90 & 0.30 & 0.45 & 0.60 & 0.30 \\
\hline & & MBC & 0.30 & 1.20 & 0.60 & 0.90 & 0.90 & 0.90 \\
\hline Taraxacum sp. & $1 \mathrm{st}$ & MIC & 0.075 & 0.60 & 0.45 & 0.20 & 0.20 & 0.20 \\
\hline & & MBC & 0.15 & 0.90 & 0.60 & 0.30 & 0.30 & 0.60 \\
\hline & 2nd & MIC & 0.075 & 0.30 & 0.45 & 0.90 & 0.20 & 0.30 \\
\hline & & MBC & 0.15 & 0.60 & 0.60 & 1.20 & 0.30 & 0.60 \\
\hline Taraxacum officinale & $1 \mathrm{st}$ & MIC & 0.037 & 0.30 & 0.30 & 0.15 & 0.15 & 0.15 \\
\hline & & MBC & 0.075 & 0.60 & 0.60 & 0.30 & 0.30 & 0.30 \\
\hline & 2nd & MIC & 0.20 & 0.90 & 0.90 & 0.30 & 0.30 & 0.60 \\
\hline & & MBC & 0.30 & 1.20 & 1.20 & 0.45 & 0.45 & 0.90 \\
\hline Streptomycin & & MIC & 0.10 & 0.04 & 0.20 & 0.20 & 0.20 & 0.20 \\
\hline & & MBC & 0.20 & 0.10 & 0.30 & 0.30 & 0.30 & 0.30 \\
\hline Ampicillin & & MIC & 0.25 & 0.25 & 0.40 & 0.40 & 0.25 & 0.75 \\
\hline & & MBC & 0.40 & 0.45 & 0.50 & 0.50 & 0.50 & 1.20 \\
\hline Species & Growing & Antif & ngal activity & & & & & \\
\hline & period & & $\begin{array}{l}\text { Aspergillus } \\
\text { fumigatus }\end{array}$ & Aspergillus ochraceus & Aspergillus niger & $\begin{array}{l}\text { Penicillium } \\
\text { funiculosum }\end{array}$ & $\begin{array}{l}\text { Penicillium } \\
\text { ochrochloron }\end{array}$ & $\begin{array}{l}\text { Penicillium } \\
\text { cyclopium }\end{array}$ \\
\hline Reichardia picroides & $1 \mathrm{st}$ & MIC & 0.60 & 0.075 & 0.60 & 0.30 & 0.60 & - \\
\hline & & MFC & 1.20 & 0.15 & 1.20 & 0.60 & 1.20 & - \\
\hline & 2nd & MIC & 0.30 & 0.037 & 0.30 & 0.30 & 0.60 & - \\
\hline & & MFC & 0.60 & 0.075 & 0.60 & 0.60 & 1.20 & - \\
\hline Hymenonema & $1 \mathrm{st}$ & MIC & - & 0.15 & - & - & - & - \\
\hline graecum & & MFC & - & 0.30 & - & - & - & - \\
\hline & 2nd & MIC & - & 0.075 & - & 0.60 & 0.60 & - \\
\hline & & MFC & - & 0.15 & - & 1.20 & 1.20 & - \\
\hline Sonchus oleraceus & $1 \mathrm{st}$ & MIC & 0.45 & 0.10 & 0.60 & 0.45 & - & - \\
\hline & & MFC & 0.90 & 0.15 & 1.20 & 0.90 & - & - \\
\hline & 2nd & MIC & 0.90 & 0.037 & 0.90 & 0.60 & 0.90 & - \\
\hline & & MFC & 1.20 & 0.075 & 1.20 & 1.20 & 1.20 & - \\
\hline Scolymus hispanicus & 2nd & MIC & 0.45 & 0.10 & 0.60 & 0.45 & 0.30 & 0.60 \\
\hline & & MFC & 0.90 & 0.30 & 0.90 & 0.90 & 0.90 & 1.20 \\
\hline Hedypnois cretica & 2nd & MIC & 0.90 & 0.15 & 0.45 & 0.30 & 0.20 & 0.30 \\
\hline & & MFC & 1.20 & 0.30 & 0.90 & 0.60 & 0.60 & 0.60 \\
\hline Picris echioides & 1st & MIC & 0.15 & 0.075 & 0.30 & 0.45 & 0.30 & 0.45 \\
\hline & & MFC & 0.30 & 0.15 & 0.60 & 0.60 & 0.60 & 0.60 \\
\hline & 2nd & MIC & 0.20 & 0.037 & 0.30 & 0.15 & 0.15 & 0.15 \\
\hline & & MFC & 0.60 & 0.075 & 0.60 & 0.30 & 0.30 & 0.30 \\
\hline Urospermum picroides & 1st & MIC & 0.60 & 0.20 & 0.60 & 0.45 & 0.60 & 0.60 \\
\hline & & MFC & 0.90 & 0.30 & 1.20 & 0.60 & 1.20 & 1.20 \\
\hline & 2nd & MIC & 0.15 & 0.075 & - & 0.20 & 0.20 & 0.45 \\
\hline & & MFC & 0.30 & 0.15 & - & 0.30 & 0.30 & 0.90 \\
\hline Taraxacum sp. & $1 \mathrm{st}$ & MIC & 0.30 & 0.10 & 0.60 & 0.15 & 0.30 & 0.30 \\
\hline & & MFC & 0.60 & 0.15 & 0.90 & 0.30 & 0.60 & 0.60 \\
\hline & 2nd & MIC & 0.15 & 0.037 & 0.30 & 0.60 & 0.20 & 0.30 \\
\hline & & MFC & 0.30 & 0.075 & 0.60 & 1.20 & 0.30 & 0.90 \\
\hline
\end{tabular}


Table 6 (continued)

\begin{tabular}{|c|c|c|c|c|c|c|c|c|}
\hline \multirow[t]{2}{*}{ Species } & \multirow{2}{*}{$\begin{array}{l}\text { Growing } \\
\text { period }\end{array}$} & \multicolumn{7}{|c|}{ Antibacterial activity } \\
\hline & & & Bacillus cereus & Staphylococcus aureus & $\begin{array}{l}\text { Listeria } \\
\text { monocytogenes }\end{array}$ & Escherichia coli & Enterobacter cloacae & $\begin{array}{l}\text { Salmonella } \\
\text { typhimurium }\end{array}$ \\
\hline \multirow[t]{4}{*}{ Taraxacum officinale } & \multirow[t]{2}{*}{1 st } & MIC & 0.45 & 0.20 & - & 0.45 & - & - \\
\hline & & MFC & 0.60 & 0.30 & - & 0.60 & - & - \\
\hline & \multirow[t]{2}{*}{ 2nd } & MIC & 0.45 & 0.20 & - & 0.60 & 0.60 & - \\
\hline & & MFC & 0.90 & 0.30 & - & 0.90 & 1.20 & - \\
\hline \multirow[t]{2}{*}{ Ketoconazole } & & MIC & 0.25 & 0.20 & 0.20 & 0.20 & 2.50 & 0.20 \\
\hline & & MFC & 0.50 & 0.50 & 0.50 & 0.50 & 3.50 & 0.30 \\
\hline \multirow[t]{2}{*}{ Bifonazole } & & MIC & 0.15 & 0.10 & 0.15 & 0.20 & 0.20 & 0.10 \\
\hline & & MFC & 0.20 & 0.20 & 0.20 & 0.25 & 0.25 & 0.20 \\
\hline
\end{tabular}

- No activity.

that microclimate conditions and genetic material are essential for chemical composition of wild edible species. Regarding Taraxacum species, $\alpha$-, $\beta$ - and $\gamma$-tocopherol were also detected in vegetative parts of Taraxacum sect. Ruderalia by Dias et al. (2014). However, $\delta$-tocopherol was not detected in that study, which is in contrast with our results, as well as with the results reported by Morales et al. (2014) for Taraxacum obovatum and Šircelj, Mikulic-Petkovsek, Veberič, Hudina, and Slatnar (2018), who did not detect any tocopherol isoforms in T. officinale edible parts.

Organic acids content is presented in Table 5, with oxalic acid being the most abundant organic acid in all the studied species and growing periods, followed by malic and shikimic acid. According to the review study of Pinela et al. (2017), wild edible greens show a great diversity in organic acids content and oxalic acid in particular, while the same authors indicated that $S$. oleraceus presents a value higher than 2.5 regarding the ratio of oxalic acid/Ca and could be considered as potentially toxic if consumed in high amounts. Moreover, in most cases oxalic acid and shikimic acid, as well as total organic acids increased in the second growing period of our study, except for the case of $H$. graecum and $\mathrm{S}$. oleraceus where the opposite trend was observed. Similarly, malic acid increased in the second growing period except for the cases of $R$. picroides, $H$. graecum and $T$. officinale. Oxalic acid is considered an antinutrient and results in adverse health effects when consumed in great amounts $(5 \mathrm{~g}$ is the minimum lethal dose for an adult) (Morales et al., 2014). However, considering that most of the wild edible species are usually consumed in low amounts as side dishes or in mixed vegetable dishes, there is no risk of high ingestion of oxalic acid even in the case of species that contain high amounts of this organic acid (e.g. H. graecum and $R$. picroides which contain up to 972 and

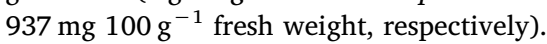

The antimicrobial activity of plant extracts is presented in Table 6. Bacteriostatic activity ranged from 0.037 to $0.90 \mathrm{mg} \mathrm{mL}^{-1}$, whereas positive controls of ampicillin and streptomycin presented MIC values ranging from 0.04 to $0.75 \mathrm{mg} \mathrm{mL}^{-1}$. In addition, bactericidal activity varied between the species and growing periods with MBC values ranging between $0.15 \mathrm{mg} \mathrm{mL}^{-1}$ and $1.20 \mathrm{mg} \mathrm{mL}^{-1}$, whereas positive controls of ampicillin and streptomycin presented values between $0.10 \mathrm{mg} \mathrm{mL}^{-1}$ and $1.20 \mathrm{mg} \mathrm{mL}^{-1}$. S. hispanicus, P. echioides, Taraxacum sp. and T. officinale showed higher bacteriostatic and bactericidal potency against Bacillus aureus than both positive controls, while the rest of the studied species were more potent only comparing to ampicillin. Similarly, S. hispanicus, $P$. echioides and T. officinale showed significant and higher than positive controls bactericidal and bacteriostatic activity against Salmonella tymphimurium, while the rest of the species were more effective than ampicillin. Antibacterial activities have been already reported for Taraxacum sp. (Ghaima et al., 2013; Kenny et al., 2014; Wang, 2014), Sonchus spp. (Xia et al., 2011) and Scolymus hispanicus (Marmouzi et al., 2017) against various food borne pathogens, such as Salmonella enterica, S. typhi, Staphylococcus aureus, B. cereus and E. coli. Regarding antifungal activities, all the studied species showed higher efficiency against Penicillium ochrochloron than ketoconazole, whereas only $P$. echiodes, $U$. picroides, and Taraxacum sp. (samples from the 2nd growing period) had higher or similar fungistatic efficiency to bifonazole against $P$. funiculosum and $P$. ochrochloron. Similarly, the same species were more effective than ketoconazole against Aspergillus fumigatus, while they also presented similar fungistatic efficiency to bifonazole. Finally, the studied species presented significant efficacy against $A$. ochraceus, where in most cases MIC and MFC values of plant extracts were lower than those of positive controls (bifonazole and ketoconazole), especially for $R$. picroides, $S$. oleraceus, $P$. echioides and Taraxacum sp. which presented the lowest values. Antonia et al. (2011) have also suggested significant antifungal properties of $S$. oleraceus extracts against Aspergillus niger and Penicillium italicum, whereas to the best of our knowledge there are no available reports in the literature for the rest of the species.

The antimicrobial properties of these species could be attributed to their high content in phenolic compounds which have been associated with the control of food borne pathogens (Kenny et al., 2014).

\section{Conclusion}

The investigation of wild edible species belonging to Asteraceae family showed a great diversity in terms of chemical composition of the edible parts, while to the best of our knowledge phytochemical composition for some of the studied species is presented for the first time. All the studied species contained mostly flavonoids, whereas only in the case of Taraxacum officinale flavonoids and phenolic acids content was detected in similar amounts. In addition, the highest content of phenolic compounds was detected in Sonchus oleraceus, while the highest content of total tocopherols was observed in Taraxacum sp. plants during the 1st growing period, mostly due to the presence of high amounts of $\gamma$ - and $\delta$ tocopherols. In terms of organic acids, oxalic acid was the most abundant acid for all the studied species, while its content was the lowest in Taraxacum species, regardless of the growing period. Moreover, cultivation of these species for commercial purposes shows a great potential for using them as rich dietary sources of bioactive compounds such as phenolic compounds and tocopherols, although special attention should be given to oxalic acid content which is considered as an antinutritional factor. Therefore, these species could be considered as functional ingredients of healthy diets contributing to wellbeing of consumers, while at the same time all-year availability could be ensured and risk for genetic erosion could be minimized. Moreover, with commercial cultivation practices and the scheduling of growing period, chemical composition could be improved and a further increase of the nutritional value of the studied species could be achieved. Finally, antimicrobial properties of the plant extracts showed promising results and could be incorporated in the food processing industry as alternative food preservatives in processed or minimally processed food products. 


\section{Acknowledgements}

The authors are grateful to the Foundation for Science and Technology (FCT, Portugal) and FEDER under Programme PT2020 for financial support to CIMO (UID/AGR/00690/2013), A. Feitor (SFRH/ $\mathrm{BPD} / 114753 / 2016$ ) and L. Barros contract; also to FEDER-Interreg España-Portugal Programme for financial support through the project 0377_Iberphenol_6_E, and to Serbian Ministry of Education, Science and Technological Development, grant No. 173032.

\section{Appendix A. Supplementary data}

Supplementary data to this article can be found online at https:// doi.org/10.1016/j.foodres.2018.10.069.

\section{References}

Albuquerque, B. R., Prieto, M. A., Vazquez, J. A., Filomena, M., Barros, L., \& Ferreira, I. C. F. R. (2018). Recovery of bioactive compounds from Arbutus unedo L. fruits: Comparative optimization study of maceration/microwave/ultrasound extraction techniques. Food Research International, 109, 455-471. https://doi.org/10.1016/j. foodres.2018.04.061.

Antonia, M., Ippolito, A., Linsalata, V., Cascarano, N. A., Nigro, F., Vanadia, S., \& Di, D. (2011). Activity of extracts from wild edible herbs against postharvest fungal diseases of fruit and vegetables. Postharvest Biology and Technology, 61(1), 72-82. https://doi. org/10.1016/j.postharvbio.2011.02.005.

Antonia, M., Sergio, L., Ippolito, A., \& Di, D. (2016). Phenolic extracts from wild edible plants to control postharvest diseases of sweet cherry fruit. Postharvest Biology and Technology, 120, 180-187. https://doi.org/10.1016/j.postharvbio.2016.06.010.

Backes, E., Pereira, C., Barros, L., Prieto, M. A., Kamal, A., Filomena, M., \& Ferreira, I. C. F. R. (2018). Recovery of bioactive anthocyanin pigments from Ficus carica L. peel by heat, microwave, and ultrasound based extraction techniques. Food Research International, 113, 197-209. https://doi.org/10.1016/j.foodres.2018.07.016.

Barros, L., Pereira, C., \& Ferreira, I. C. F. R. (2013). Optimized analysis of organic acids in edible mushrooms from Portugal by ultra fast liquid chromatography and photodiode array detection. Food Analytical Methods, 6(1), 309-316. https://doi.org/10.1007/ s12161-012-9443-1.

Barros, L., Pereira, E., Calhelha, R. C., Dueñas, M., Carvalho, A. M., Santos-Buelga, C., \& Ferreira, I. C. F. R. (2013). Bioactivity and chemical characterization in hydrophilic and lipophilic compounds of Chenopodium ambrosioides L. Journal of Functional Foods, 5(4), 1732-1740. https://doi.org/10.1016/j.jff.2013.07.019.

Becker, C., Klaering, H., Schreiner, M., Kroh, L. W., \& Krumbein, A. (2014). Unlike quercetin glycosides, cyanidin glycoside in red leaf lettuce responds more sensitively to increasing low radiation intensity before than after head formation has started. Journal of Agricultural and Food Chemistry, 62, 6911-6917. https://doi.org/10.1021/ jf404782n.

Bessada, S. M. F., Barreira, J. C. M., Barros, L., Ferreira, I. C. F. R., \& Oliveira, M. B. P. P. (2016). Phenolic profile and antioxidant activity of Coleostephus myconis (L.) Rchb.f.: An underexploited and highly disseminated species. Industrial Crops and Products, 89, 45-51. https://doi.org/10.1016/j.indcrop.2016.04.065.

Chatzigianni, M., Alkhaled, B., Livieratos, I., Stamatakis, A., Ntatsi, G., \& Savvas, D. (2017). Impact of nitrogen source and supply level on growth, yield and nutritional value of two contrasting ecotypes of Cichorium spinosum L. grown hydroponically. Journal of the Science of Food and Agriculture, 98(4), 1615-1624. https://doi.org/10. $1002 /$ jsfa. 8636

Chen, H., Inbaraj, B. S., \& Chen, B. (2012). Determination of Phenolic Acids and Flavonoids in Taraxacum formosanum Kitam by Liquid Chromatography- Tandem Mass Spectrometry coupled with a post-column derivatization technique. International Journal of Molecular Sciences, 13, 260-285. https://doi.org/10.3390/ ijms13010260.

Conforti, F., Marrelli, M., Carmela, C., Menichini, F., Valentina, P., Uzunov, D., ... Menichini, F. (2011). Bioactive phytonutrients (omega fatty acids, tocopherols, polyphenols), in vitro inhibition of nitric oxide production and free radical scavenging activity of non-cultivated Mediterranean vegetables. Food Chemistry, 129(4), 1413-1419. https://doi.org/10.1016/j.foodchem.2011.05.085.

Dias, I. M., Barros, L., Alves, R. C., Oliveira, M. B. P. P., Santos-Buelga, C., \& Ferreira, I. C. F. R. (2014). Nutritional composition, antioxidant activity and phenolic compounds of wild Taraxacum sect. Ruderalia. Food Research International, 56, 266-271. https:// doi.org/10.1016/j.foodres.2014.01.003.

Domínguez, R., Barba, F. J., Gómez, B., Putnik, P., Kovačević, D. B., Pateiro, M., Lorenzo, J. M. (2018). Active packaging fi lms with natural antioxidants to be used in meat industry: A review. Food Research International Journal, 113, 93-101. https:// doi.org/10.1016/j.foodres.2018.06.073.

Fallovo, C., Schreiner, M., Schwarz, D., Colla, G., \& Krumbein, A. (2011). Phytochemical changes induced by different nitrogen supply forms and radiation levels in two leafy brassica species. Journal of Agricultural and Food Chemistry, 59(8), 4198-4207. https://doi.org/10.1021/jf1048904.

Fragopoulou, E., Detopoulou, P., Nomikos, T., Pliakis, E., Panagiotakos, D. B., \& Antonopoulou, S. (2012). Mediterranean wild plants reduce postprandial platelet aggregation in patients with metabolic syndrome. Metabolism, 61(3), 325-334. https://doi.org/10.1016/j.metabol.2011.07.006.

Ghaima, K. K., Hashim, N. M. \& Ali, S. A. (2013). Antibacterial and antioxidant activities of ethyl acetate extract of nettle (Urtica dioica) and dandelion (Taraxacum officinale). Journal of Applied and Pharmaceutical Science, 3(05), 96-99. https://doi.org/10.7324/ JAPS.2013.3518.

Giacometti, J., Kovačević, D. B., Putnik, P., Gabrić, D., Bilusić, T., Kresic, G., ... Jambrak, A. R. (2018). Extraction of bioactive compounds and essential oils from mediterranean herbs by conventional and green innovative techniques: A review. Food Research International Journal, 113, 245-262. https://doi.org/10.1016/j.foodres.2018.06.036.

Giner, R. M., Ubeda, A., Just, M. J., Serrano, A., Manez, S., \& Rios, J. (1993). A chemotaxonomic survey of Sonchus subgenus Sonchus. Biochemical Systematics and Ecology, 21(5), 617-620. https://doi.org/10.1016/0305-1978(93)90062-V.

Guarrera, P. M., \& Savo, V. (2013). Perceived health properties of wild and cultivated food plants in local and popular traditions of Italy: A review. Journal of Ethnopharmacology, 146, 659-680. https://doi.org/10.1016/j.jep.2013.01.036.

Guarrera, P. M., \& Savo, V. (2016). Wild food plants used in traditional vegetable mixtures in Italy. Journal of Ethnopharmacology, 185, 202-234. https://doi.org/10.1016/ j.jep.2016.02.050.

Guil, J. L., Rodríguez-García, I., \& Torija, E. (1997). Nutritional and toxic factors in selected wild edible plants. Plant Foods for Human Nutrition, 51, 99-107. https://doi. org/10.1023/A:100798881.

Huo, B.-S., \& Qin, M.-J. (2008). Content analysis of flavonoids in five species of Sonchus L. Journal of Plant Resources and Environment, 17(2), 77-78. https://doi.org/10.1186/ 1752-153X-6-126.

Kenny, O., Smyth, T. J., Walsh, D., Kelleher, C. T., Hewage, C. M., \& Brunton, N. P. (2014). Investigating the potential of under-utilised plants from the Asteraceae family as a source of natural antimicrobial and antioxidant extracts. Food Chemistry, 161 79-86. https://doi.org/10.1016/j.foodchem.2014.03.126.

Leonti, M., Nebel, S., Rivera, D., \& Heinrich, M. (2006). Wild gathered food plants in the European Mediterranean: a comparative analysis. Economic Botany, 60(2), 130-142. https://doi.org/10.1663/0013-0001(2006)60[130:WGFPIT]2.0.CO;2.

Li, Q., Dong, D., Huang, Q., Li, J., Du, Y., \& Li, B. (2017). The anti-inflammatory effect of Sonchus oleraceus aqueous extract on lipopolysaccharide stimulated RAW 264.7 cells and mice. Pharmaceutical Biology, 55(1), 799-809. https://doi.org/10.1080/ 13880209.2017.1280514.

Łuczaj, Ł., \& Dolina, K. (2015). A hundred years of change in wild vegetable use in southern Herzegovina. Journal of Ethnopharmacology, 166, 297-304. https://doi.org/ 10.1016/j.jep.2015.02.033.

Marmouzi, I., El Karbane, M., El Hamdani, M., Kharbach, M., Mrabti, H. N., Alami, R., ... Faouzi, A. (2017). Phytochemical and pharmacological variability in golden thistle functional parts: comparative study of roots, stems, leaves and flowers. Natural Product Research, 6419, 1-6. https://doi.org/10.1080/14786419.2017.1283494.

Martinez, M., Poirrier, P., Chamy, R., Prüfer, D., Schulze-Gronover, C., Jorquera, L., \& Ruiz, G. (2015). Taraxacum officinale and related species - An ethnopharmacological review and its potential as a commercial medicinal plant. Journal of Ethnopharmacology, 169, 244-262. https://doi.org/10.1016/j.jep.2015.03.067.

Morales, P., Carvalho, A. M., Sánchez-Mata, M. C., Cámara, M., Molina, M., \& Ferreira, I. C. F. R. (2012). Tocopherol composition and antioxidant activity of Spanish wild vegetables. Genetic Resources and Crop Evolution, 59(5), 851-863. https://doi.org/10. 1007/s10722-011-9726-1.

Morales, P., Ferreira, I. C. F. R., Carvalho, A. M., Sánchez-Mata, M. C., Cámara, M., Fernández-Ruiz, V., ... Tardío, J. (2014). Mediterranean non-cultivated vegetables as dietary sources of compounds with antioxidant and biological activity. LWT - Food Science and Technology, 55(1), 389-396. https://doi.org/10.1016/j.lwt.2013.08.017.

Mousavi, A., Hashemi, S. M. B., \& Limbo, S. (2018). Food and Bioproducts Processing Antimicrobial agents and packaging systems in antimicrobial active food packaging: An overview of approaches and interactions. Food and Bioproducts Processing, 111, 1-19. https://doi.org/10.1016/j.fbp.2018.05.001.

Pateiro, M., Barba, F. J., Domínguez, R., Sant'Ana, A. S., Khaneghan, A. M., Gavahian, M., ... Lorenzo, J. M. (2018). Essential oils as natural additives to prevent oxidation reactions in meat and meat products: A review. Food Research International, 113, 156-166. https://doi.org/10.1016/j.foodres.2018.07.014.

Pérez-López, U., Miranda-Apodaca, J., Muñoz-Rueda, A., \& Mena-Petite, A. (2015). Interacting effects of high light and elevated $\mathrm{CO}_{2}$ on the nutraceutical quality of two differently pigmented Lactuca sativa cultivars (Blonde of Paris Batavia and Oak Leaf). Scientia Horticulturae, 191, 38-48. https://doi.org/10.1016/j.scienta.2015.04.030.

Petropoulos, S., Fernandes, Â., Karkanis, A., Antoniadis, V., Barros, L., \& Ferreira, I. C. F. R. (2018). Nutrient solution composition and growing season affect yield and chemical composition of Cichorium spinosum plants. Scientia Horticulturae, 231, 97-107. https://doi.org/10.1016/j.scienta.2017.12.022.

Petropoulos, S., Fernandes, Â., Karkanis, A., Ntatsi, G., Barros, L., \& Ferreira, I. C. F. R. (2017). Successive harvesting affects yield, chemical composition and antioxidant activity of Cichorium spinosum L. Food Chemistry, 237, 83-90. https://doi.org/10. 1016/j.foodchem.2017.05.092.

Petropoulos, S. A., Karkanis, A., Martins, N., \& Ferreira, I. C. F. R. (2018). Edible halophytes of the Mediterranean basin: Potential candidates for novel food products. Trends in Food Science \& Technology, 74, 69-84. https://doi.org/10.1016/j.tifs.2018. 02.006.

Petropoulos, S. A., Ntatsi, G., Levizou, E., Barros, L., \& Ferreira, I. C. F. R. (2016). Nutritional profile and chemical composition of Cichorium spinosum ecotypes. LWT Food Science and Technology, 73, 95-101. https://doi.org/10.1016/j.lwt.2016.05. 046.

Pieroni, A., \& Quave, C. (Eds.). (2014). Ethnobotany and Biocultural Diversities in the Balkans. New York: Springer.

Pinela, J., Carvalho, A. M., \& Ferreira, I. C. F. R. (2017). Wild edible plants : Nutritional and toxicological characteristics, retrieval strategies and importance for today's 
society. Food and Chemical Toxicology, 110, 165-188. https://doi.org/10.1016/j.fct. 2017.10.020.

Psaroudaki, A., Nikoloudakis, N., Skaracis, G., \& Katsiotis, A. (2015). Genetic structure and population diversity of eleven edible herbs of Eastern Crete. Journal of Biological Research (Thessalonikē, Greece), 22(1), 7. https://doi.org/10.1186/s40709-0150030-7.

Recio, M. C., Giner, R. M., Hermenegildo, M., Peris, J. B., Iez, I. S. M. A. I., \& Rios, J. (1992). Phenolics of Reichardia and their taxonomic implications. Biochemical Systematics and Ecology, 20(5), 449-452. https://doi.org/10.1016/0305-1978(92) 90085-R.

Sánchez-Mata, M. C., Loera, R. D. C., Morales, P., Fernández-Ruiz, V., Cámara, M., Marqués, C. D., ... Tardío, J. (2012). Wild vegetables of the Mediterranean area as valuable sources of bioactive compounds. Genetic Resources and Crop Evolution, 59(3), 431-443. https://doi.org/10.1007/s10722-011-9693-6.

Schaffer, S., Schmitt-Schillig, S., Müller, W. E., \& Eckert, G. P. (2005). Antioxidant properties of Mediterranean food plant extracts: Geographical differences. Journal of Physiology and Pharmacology, 56(Suppl. 1), 115-124. Retrieved from https://www, scopus.com/inward/record.uri?eid = 2-s2.0-26044431755\&partnerID = 40\&md5 = df12a3925ad0fa57ee4ddb9fef8255a5.

Schütz, K., Kammerer, D. R., Carle, R., \& Schieber, A. (2005). Characterization of phenolic acids and flavonoids in dandelion (Taraxacum officinale WEB. ex WIG.) root and herb by high-performance liquid chromatography / electrospray ionization mass spectrometry. Rapid Communications in Mass Spectometry, 19, 179-186. https://doi. org $/ 10.1002 / \mathrm{rcm} .1767$.

Simopoulos, A. P. (2004). Omega-3 fatty acids and antioxidants in edible wild plants. Biological Research, 37(2), 263-277. https://doi.org/10.4067/S071697602004000200013.

Šircelj, H., Mikulic-Petkovsek, M., Veberič, R., Hudina, M., \& Slatnar, A. (2018). Lipophilic antioxidants in edible weeds from agricultural areas. Turkish Journal of Agriculture and Forestry, 42, 1-10. https://doi.org/10.3906/tar-1707-25.

Trichopoulou, A., Vasilopoulou, E., Hollman, P., Chamalides, C., Foufa, E., Kaloudis, T., .. Theophilou, D. (2000). Nutritional composition and flavonoid content of edible wild greens and green pies: A potential rich source of antioxidant nutrients in the Mediterranean diet. Food Chemistry, 70(3), 319-323. https://doi.org/10.1016/ S0308-8146(00)00091-1.

Vardavas, C. I., Majchrzak, D., Wagner, K. H., Elmadfa, I., \& Kafatos, A. (2006). The antioxidant and phylloquinone content of wildly grown greens in Crete. Food Chemistry, 99(4), 813-821. https://doi.org/10.1016/j.foodchem.2005.08.057.

Wang, H. (2014). Effect of dandelion polysaccharides on the retardation of the quality changes of white shrimp. International Journal of Biological Macromolecules, 68, 205-208. https://doi.org/10.1016/j.ijbiomac.2014.05.002.

Xia, D.-Z., Yu, X.-F., Zhu, Z.-Y., \& Zou, Z.-D. (2011). Antioxidant and antibacterial activity of six edible wild plants (Sonchus spp.) in China. Natural Product Research, 25(20), 1893-1901. https://doi.org/10.1080/14786419.2010.534093. 